Journal of

\title{
A Real Option Approach for the Valuation of Switching Output Flexibility in Residential Property Investment
}

\begin{tabular}{|r|l|}
\hline Journal: & Journal of Financial Management of Property and Construction \\
\hline Manuscript ID & JFMPC-05-2017-0017.R4 \\
\hline Manuscript Type: & Research Paper \\
\hline Keywords: & $\begin{array}{l}\text { real options, DCF, Valuation, residential property investment, } \\
\text { Flexibility(Switching output), uncertainties and risks }\end{array}$ \\
\hline \multicolumn{2}{|l}{} \\
\hline
\end{tabular}

SCHOLARONE

Manuscripts 
Tables in manuscript

Table 1 Switching output table for residential part of the mixed use building

\begin{tabular}{|r|r|r|r|r|r|}
\hline \multicolumn{4}{|c|}{ Residential Apartment } & \multicolumn{3}{c|}{ Student Studio Accommodation (SSA) } \\
\hline Current Units & Current size & No of units & SSA sizes & Switch & Total SSAs \\
\hline 1 bedroom & 25sq.m & 82units & 25sq.m & 2SSAs & $164 S S A s$ \\
\hline 2 bedrooms & 65sq.m & 80units & 65 sq.m & 3SSAs & $240 S S A s$ \\
\hline 3 bedrooms & 90sq.m & 2units & 90sq.m & 5SSAs & $10 S S A s$ \\
\hline
\end{tabular}

Source: Authors, 2017

Table 2 Switching output table for commercial part of the mixed use building

\begin{tabular}{|c|c|c|c|c|}
\hline \multicolumn{5}{|c|}{ Commercial Part (Coworking spaces/consultancy/ and car parking) } \\
\hline Space type & Quantity/size & Switch output & Quantity & Size \\
\hline Retail & 880 sqm & Offices (combined) & 1 & $880 \mathrm{sqm}$ \\
\hline Car park & 115 spaces & Offices (combined) & 1 & $880 \mathrm{sqm}$ \\
\hline
\end{tabular}


Table 3 Data on the original project design for DCF modelling

\begin{tabular}{l|rrr} 
Units & Quantity & Net Rent/week(\$AUD) & Total rent/year(\$AUD) \\
\hline droom & 82 & $\$ 360$ & $\$ 1,236,560$ \\
retail & 80 & $\$ 480$ & $\$ 1,614,080$ \\
& 2 & $\$ 670$ & $\$ 56,264$ \\
& 4 & $\$ 410 /$ sq.m./p.a & $\$ 360,800$
\end{tabular}

Adapted: Urban Melbourne (2015), UniLodge (2017) and Savills (2016) 
Table 4 Switching output table and projected rents for different spaces

\begin{tabular}{|c|c|c|c|c|c|c|}
\hline \multicolumn{7}{|c|}{ Student Studio Accommodation (Rooms) } \\
\hline Units & Total & Switch output & After switch & Total after switch & $\begin{array}{c}\text { Gross rent } p / w \\
\text { (\$AUD) }\end{array}$ & $\begin{array}{c}\text { Total/gross p.a } \\
\text { (\$AUD) }\end{array}$ \\
\hline 1 bedroom & 82 & Studios (2 rooms) & 2 & 164 & $\$ 310$ & $\$ 2,643,680$ \\
\hline 2 bedrooms & 80 & Studios (3 rooms) & 3 & 240 & $\$ 310$ & $\$ 3,868,800$ \\
\hline 3 bedrooms & 2 & Studios (5 rooms) & 5 & 10 & $\$ 310$ & $\$ 161,200$ \\
\hline Total & 164 & & & 414 & $\$ 930$ & $\$ 6,673,680$ \\
\hline \multicolumn{7}{|c|}{ Commercial Part (Coworking spaces/consultancy/ and car parking) } \\
\hline Space type & Quantity/size & Switch output & Quantity & Size/quantity & Rent (\$AUD) & $\begin{array}{c}\text { Total gross rent } \\
\text { (\$AUD) }\end{array}$ \\
\hline Retail & 880 sqm & Offices (combined) & 1 & 880 sq.m & $\$ 236 /$ sq.m/p.a & $\$ 207,680$ \\
\hline Car park & 115 spaces & Offices (combined) & 1 & 880 sq.m & $\$ 236 /$ sq.m/p.a & $\$ 207,680$ \\
\hline Total p.a & \multicolumn{5}{|c|}{ 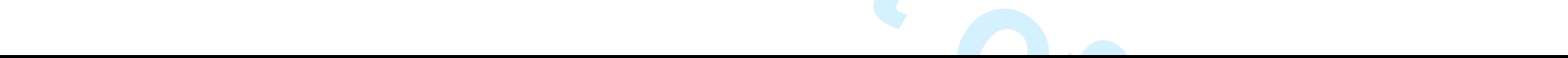 } & $\$ 415,360$ \\
\hline \multicolumn{6}{|c|}{ Total for whole building } & $\$ 7,089,040$ \\
\hline
\end{tabular}

Table 5 DCF profitability information

\begin{tabular}{l|l} 
Profitability measure & \multicolumn{1}{l}{ Value } \\
\hline Net Present Value & \$AUD1,189,441 \\
Internal Rate of Return & $11.5 \%$ \\
Initial Yield & $6.9 \%$
\end{tabular}




\section{A Real Option Approach for the Valuation of Switching Output Flexibility in Residential Property Investment}

\subsection{Introduction}

In the $21^{\text {st }}$ century, flexibility has become an important consideration across all economic sectors due to the pace at which changes occur and the direct impact on businesses. In the property and construction sector, these changes can have serious financial consequences due to long investment horizons, and the difficulty and costly nature of retrofitting and adapting existing buildings to suit the changing needs of occupiers. As a result, flexibility in buildings has become an important issue in property developments and investments. This is heightened for major investor-developers (ID's) (for example property fund managers, pension funds, real estate investment trusts etc.) who instigate developments with the aim of holding as part of an existing portfolio so as to increase possible returns and provide access to quality property assets or offer a development revenue stream to compliment the property portfolio.

Residential properties have become an important asset in the portfolio of long term investments and numerous studies have argued that, housing is an effective investment vehicle. This is primarily due to the diversification benefits derived from residential property investments in a mixed asset portfolio, resulting from its low correlation with other major asset classes as supported by academic studies, see Cocco (2004); Goetzmann (1993); Goodman (2003); Lin Lee (2008). In Australia, some developers including ISPT and Oliver Hume have set up real estate investment funds for the purposes of residential property developments. Even though investments in residential properties offer diversification benefits in a mixed asset portfolio, the risks inherent in property development/investment cannot be overlooked. Risks including those that emanate from planning, through to construction and operational risks during the leasing phase after completion.

Due to complexity and the long term nature of property investments IDs face considerable uncertainty in their investment activities. Loizou and French (2012) indicate that uncertainties and risks in property development include land cost, cost of financing, construction, timing of development, income revenue and other socioeconomic factors. It can be argued that uncertainty associated with the revenue generated through either sales, leasing and capital growth is the most critical as it has direct impact on the profitability of investments, especially for IDs who have a long term investment horizon. In view of uncertainties in property investments, increasing occupancy rates for profit maximisation requires a long term strategy in the form of design flexibility; where buildings are capable of adapting to suit changing needs of occupiers in changing market conditions. Building flexibility can be achieved through the introduction of mobile walls, flexible floor plates, new technologies, better planning methods and open building design (Vimpari et al., 2014) during the early design stages of investment by IDs.

Flexibility in buildings that serves as strategic rights for risk mitigation and for capitalising on emerging investment opportunities can be termed as real options. Paxson (2005) suggests that options are numerous and naturally embedded in projects. Trigeorgis (1996) then identified several flexible strategies and categorised them into defer, expand, switch output or input, stage, temporary shutdown and abandonment which were later adapted in the real estate sector by Lucius (2001). These options have become key strategies in the property and construction sector as a way of mitigating risks and opening up future opportunities resulting from uncertainties. The switching output option embedded in property developments can be used as a strategy to hedge against downside risks and open up future opportunities for long term IDs. Decisions of such nature are 
generally based on changes in economic conditions in the property market. Thus, when economic conditions change unfavourably for one asset, a switch of the building to a different use that has high demand can result in better upside gains for IDs if the building is flexible for retrofitting and adaptation. As an example, an originally planned hotel could be switched to units or apartment in future if design flexibility is conceived and embedded in the investment from inception as a way of mitigating risks of high vacancy.

The switching output option requires upfront initial investment in design flexibility in order to have the opportunity to capitalise on the embedded option in the future when required. Whereas it is fairly direct to estimate the cost associated with building flexibility through the use of industry recognised software, appraising the economic value linked to these investments is not; due to uncertainties associated with future changes in occupiers needs, occupancy rates and potential future cash flows during the rental and operational phase of an investment. The focus of this research paper is to assess the economic value of embedding the flexibility to switch a mixed use (residential and retail) apartment building into a converted student accommodation (CSA) and coworking space using a case study in order to justify investment in design features that allow for flexibility. This has the potential to mitigate future risks for the ID involved in this investment project and drive investments in flexibility in practice. The findings of this paper will deliver evidence needed to support the practical application of real option models in property and construction industry. As real options models have lacked practical adoption due to the limited evidence of its usability in practice as posited by (Lander and Pinches, 1998; Oppenheimer, 2002) and the need for more case studies (Geltner and de Neufville, 2012).

Subsequent to the introduction, section two provides a literature review covering prior research in the area of building flexibility definition, valuation, application of real option valuation to building flexibility and a distinction between residential dwellings and purpose built student accommodation in the property and construction sector. Section three is dedicated to the description of the selected case study in an empirical setting, issues with the project that can potentially affect the financial viability, a switching proposal and a justification for the switching proposal. Section four details the data on the mixed use used for modelling the financial viability of the project; both DCF and real options valuation. The associated methodology was also explained in this section. Section five provides the empirical findings, discusses the findings within the context of the case study and implications for property investors/developers. The last section provides the concluding comments on the application of the real option valuation to a case study and how it improves decision making in property investments.

\subsection{Literature Review}

Economically, it is inefficient to design and invest in building flexibility without having a long term strategic direction for an investment. The reason relates to buildings that do not last for their planned economic and functional life span results in loss of revenue to affect projected return on investment (Slaughter, 2001). As a result, it is important for IDs to have a long term view of property investments and how the functional and economic life span of properties can be extended to maximise profitability. As initial extra investment is non-recoverable in building flexibility, it is important for analysts considering flexibility to evaluate and determine flexibility requirements as it will be financially imprudent to embed flexibility if not needed (Gibson, 2001). Regarding flexibility in buildings, this paper focuses on change in use with respect to how columns, floor layout, and walls, etc. are capable of adapting to new configuration for other uses. Determining the value of such 
initial extra investments that are tied to future uncertainties is not as straightforward using existing traditional valuation techniques.

The traditional valuation methods include market comparison approach, residual valuation, direct capitalisation, profits approach and cost approach. Specifically for investment valuation, the prominent approaches used in decision making are relative valuations (market comparison), discounted cash flow (DCF) and option pricing techniques (Damodaran, 2012). Relative valuation is unsuitable for appraising economic value of flexibility due to the lack of comparable evidence. DCF applies present value analysis to compute the current worth of possible future cash flows for the value of an asset. Currently, DCF is the most widely accepted technique for investment valuation in practice (Shapiro et al., 2013). However, several criticisms have been levelled against the DCF. For example, DCF does not account for managerial flexibility that can improve the upside potential associated with uncertainties while simultaneously limiting potential downside losses (French and Gabrielli, 2005; Trigeorgis and Mason, 1987). Likewise Sirmans (1997) argued that, DCF is insufficient to evaluate real estate projects. Moreover, DCF assumes investment decisions are now or never irrespective of future uncertainties attached to projected cash flows at the initial stage of an investment (Dixit and Pindyck, 1994; Dixit and Pindyck, 1995). It is this assumption of DCF that renders it weak in the face of uncertainties because it assumes a static position for investment analysis without regard to potential variations in future value resulting from managerial flexibility. Real option valuation which is based on the option pricing technique offers a plausible way of determining the value of flexibility because it considers uncertainty from a wide range of figures and combines with qualitative information to evaluate flexibility.

The real option analysis (ROA) and real option valuation (ROV) techniques combine qualitative and quantitative information in the form of future options and evaluate them as possibilities to capture uncertainties, rather than adjusting discount rates to reflect uncertainties and risks in investments. As argued by Kogut and Kulatilaka (2001), firms can proactively exploit risk rather than just absorbing it. ROA emphasises on strategic investments today, whose value may be derived in future, and combines it with the financial theory of options to determine the potential value of such investments. The value of these strategic flexible investments (switch output) are tied to uncertainties in market prices/values of the specific real estate asset as supported by de Neufville (2003) who argues that, ROA is "a blend of technical and market considerations".

In the property and construction sector, particularly land development, leading authors including Titman (1985), Quigg (1993) and Williams (1991) have all contributed to the ROA literature. In building flexibility, de Neufville et al. (2006) evaluated the option to expand a structure using a parking garage case study. The value of the flexible right embedded in building a foundation stronger than required to support the construction of a garage with the aim of expanding the garage later (based on demand) was justified through the use of ROV. The additional cost of building the foundation to support the future expansion was $5 \%$ of initial estimate, however, the value of the flexibility added to the project was in excess of \$US2.5million. Greden and Glicksman (2005) developed a model for justifying expenses in flexible design of a building, which could be renovated into an office block at a specified cost in the future. An application of the model to a case study indicated it is worth investing US\$40/sq.ft in initial investment expenses to acquire the right to renovate into an office space for US\$25/sq.ft in a period of eight years. Similarly, Greden et al. (2005) studied the conversion of a naturally ventilated building into a mechanically ventilated building and justified the viability of extra investments into flexibility resulting from expected rise in future value of the building. Using a healthcare real estate project, Dortland et al. (2012) studied different kinds of flexibility and used qualitative analysis to argue that options and scenario analysis 
can aid in the management of uncertainties. Cardin et al. (2013) followed with design catalogues as a way of reducing uncertainty to fewer scenarios for effective analysis of the value of flexible investments. It was argued that focusing on fewer uncertainties using scenario analysis simplified uncertainty assessments and the determination of real option values for decision making. However, Vimpari et al. (2014) departed from probabilistic analysis as adopted in most previous studies and used the fuzzy pay off method (FPOM) which is based on scenario analysis to evaluate the value of flexibility in a retrofit investment of a corporate office. They examined the value of flexibility accrued to both a corporation and its corporate real estate unit. It was argued that investment in flexibility from the corporation's perspective was viable, due to the high expected payoff. On the switching option, an application to a construction project has been evaluated by Trigeorgis (1993b) and concluded that the value of the flexibility to switch was almost $7 \%$ of the project's gross value. Furthermore, Patel and Paxson (1998) evaluated switching real options for a leisure development in a restricted sequential time context and found positive results. Leung and Hui (2002) evaluated several option types including the value of embedding the option to switch a hotel part of Hong Kong Disney land project. The authors found that the value of the switching option was HK\$107.4million representing 7.7 percent saving of the loss value and 0.56 percent of the gross development value of the project. Even though the evaluation suggested that there was the possibility of losses, the switching option mitigated the total losses. Paxson (2005) also found similar results in an application of the switching option in property investments. Cheah and Liu (2005) evaluated several options including switching of fuel in a large infrastructural power project and concluded that the switching option of fuel between gas and naphtha overtime have great influence on the cash flow of the project and amounted to about $4.2 \%$ of the base NPV calculated for the project.

It has been argued that research into the capability of real option techniques and its application in practice is still at early stages (Geltner and de Neufville, 2012; Lucius, 2001) and as result, there is a general consensus among prior researchers that more practical case studies are needed (Vimpari, 2014) to demonstrate the value of ROA/ROV in the real estate and construction sector. More importantly, research on the switching output option which deals with such flexibility as an ROA strategy has been limited. Since the switching output when embedded is permanent, and can be exercised at any time during the investment horizon, it is likened to a perpetual American call option and evaluated as such in this paper. The flexibility proposed in this paper is a switching from a mixed use of residential and retail to CSA and co-working offices.

Even though Australian apartment buildings and CSAs come under a broad classification of residential dwellings, the two asset classes are different. Firstly, CSAs require that all residents must be students of tertiary institutions which is not a requirement for an apartment building, as a result, the two asset classes have different target markets. In terms of bedroom sizes, the dimensions required for a bedroom in an apartment building is about 10sqm excluding living areas (Department of Environment, 2016) but, a bedroom and living room for a single student accommodation must have a minimum dimension of 10.8sqm (Department of Environment, 2011). Similarly, communal area sizes for residential apartment are set at $2.5 \mathrm{sqm}$ per dwelling as opposed to $15 \mathrm{sqm}$ for 12 students (1.25sqm per student) in CSA. Whereas the design of apartment buildings requires car parks, a CSA is designed to encourage the use of bicycles and scooters, consequently, CSAs have limited or no car parking space in some cases. Other amenities provided for residential apartment dwellings include a secured storage and private open space. CSAs on the contrary are fitted with amenities such as TV set, desk, book shelf, microwave etc. In view of these, the two asset classes are not the same.

\subsection{Case Study in Empirical Settings}




\subsection{Case Study}

A mixed use (residential and retail) development project is currently under construction in Melbourne. The development is located in North Melbourne on a land size of $1,045 \mathrm{~m} 2$. It is about $1.2 \mathrm{~km}$ from the Melbourne central business district (CBD) and noted as one of Melbourne's most walkable neighbourhoods as almost all amenities are within easy walking distance.

Figure 1 Example of a Melbourne mixed use tower (not actual building due to confidentiality)

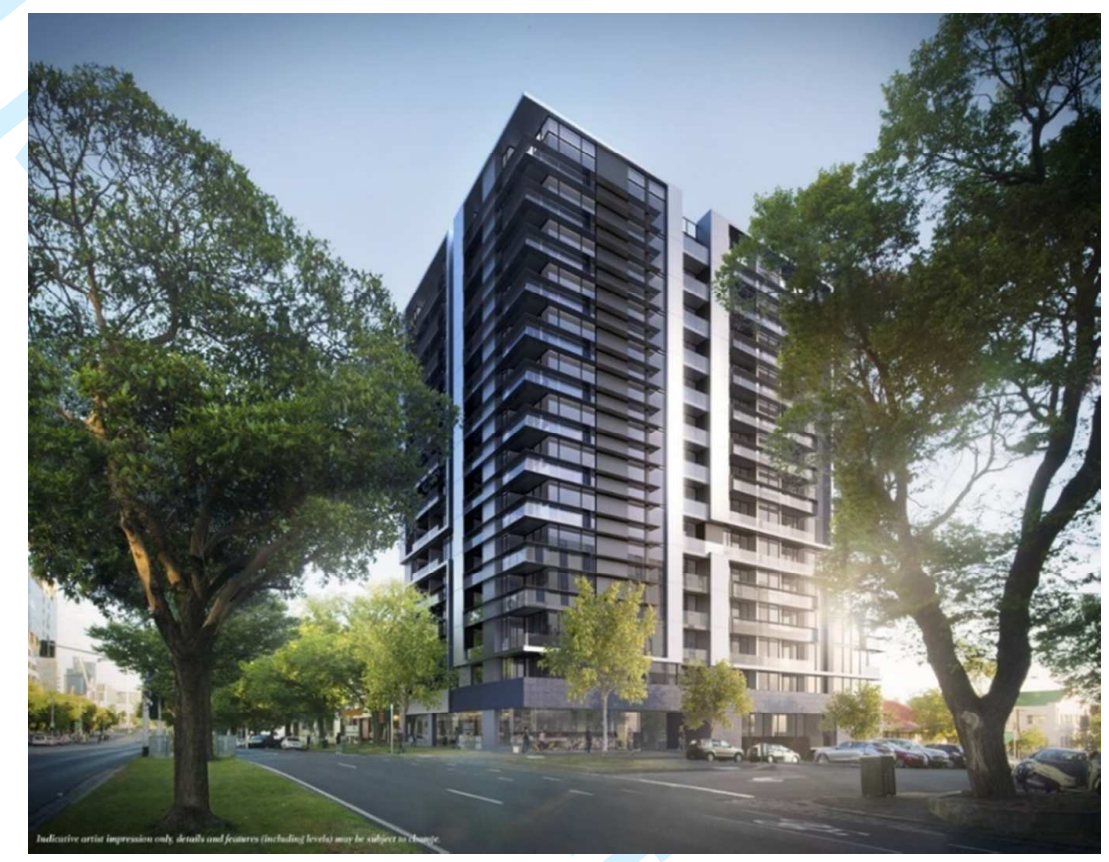

Source: Urban Melbourne (2015) (Not actual building due to confidentiality)

Figure 1 shows a similar type of mixed use development that is being constructed by the investor. In the selected development, the total number of apartments is 164 and 4 retail spaces. It has a total floor space area of approximately 10,500sq.m with an average size for 1,2 and 3 bedroom apartments being 52sq.m, 65sq.m and 95sq.m respectively. The 4 retail spaces have 220sq.m each, making a total of 880sq.m. There are 2 penthouses for high end luxurious living with excellent views of the city. The development is approximately 50 metres high, 15 levels including the basement and lower ground floors with 100 and 115 bike and car parking spaces respectively.

\subsection{Issues with the Project}

There is a high level of competition in the location of the development due to similar projects; either under construction or already completed which can affect demand. For example, there is an estimated 700 units of apartments under construction in the area which are scheduled for completion around the same time as the subject investment in 2018 (Urban Melbourne, 2015). This is likely to compress demand, occupancy rates and rents which can negatively affect the profitability of the investment as projected. Statistics from JLL (2016) indicate that, vacancy rate in the inner Melbourne area within $4 \mathrm{~km}$ radius including North Melbourne has increased to $4.3 \%$ for units in apartment buildings and it is the highest vacancy across the eastern seaboard in Australia (JLL, 2016). The statistics further suggest a decline of $8.2 \%$ year on year sales volumes across inner Melbourne and coupled with an estimated supply of about 21,170 units by 2021, there is a greater possibility of an oversupply of apartments in the future. Moreover, there is uncertainty and 
sentiments in the property market regarding supply and demand and has led to a significant decline in sales activity of development sites within the inner Melbourne area (JLL, 2016).

Figure $\mathbf{2}$ Location of competing properties in the locality and other amenities

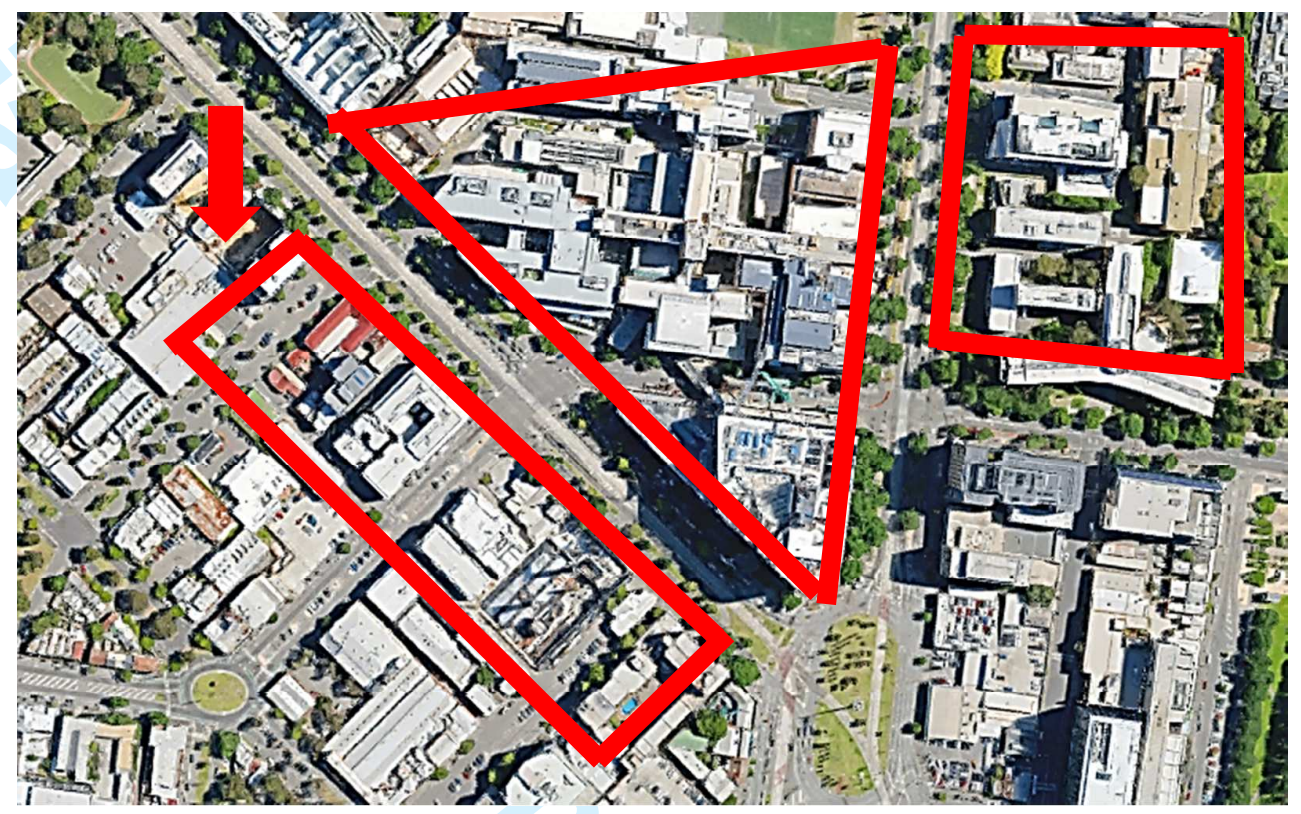

Source: Investor, 2016

In Figure 2, the triangular area in the centre is the location for a major Melbourne health care facility with other ancillary services making it an attractive area for a household location. The rectangular land area above the triangular area in Figure 2 is the location for a major university and other services which are an important driver for city living such as cafes, supermarkets, etc. The rectangular area below the triangular area has several buildings similar to the proposed development (mixed use residential and ground floor retail with car park). This poses very stiff competition for the development with possible lower profitability. The bold arrow in Figure 2 shows the site for the project at the time the site was ready for construction to commence.

\subsection{Switching Proposal (a hedge against future uncertainties and risks)}

In view of the issues raised about the investment, it is important for the investor with a long term investment horizon to develop a flexible strategy to prepare for future market uncertainties. Flexibility in the building design can enhance the building adaptability to different uses when demand for residential and retail use decreases in favour of CSAs and co-working spaces. For example, in this project, it is proposed that the development incorporates a flexible strategy to convert the apartment section into CSA. Similarly, the retail space and car park can be converted into co-working space for use by different firms because the co-working concept has been embraced by industry.

\section{Table 1 here}

The details of the switching proposal to CSA and coworking space are displayed in Table 1 . In Table 1 , it is proposed that all 1 bedroom units of size $50 \mathrm{sqm}$ in the apartment building should be embedded with the flexibility to redesign and reconfigure into a 2 bedroom shared student accommodation (SSA) with each SSA having a size of 25sq.m (bedroom-9sq.m, bathroom-5.5sq.m, living area and 
kitchenette-10sqm). Similarly, the 2 bedroom units in the apartment building can have the flexibility to be converted into 3 bedrooms SSA with 2 bathrooms, an open plan living area, and a kitchen with a total floor plate of $65 \mathrm{sq} . \mathrm{m}$. The 3 bedroom units in the apartment building on the top 2 floors can also have the flexibility to be converted into 5 SSAs with similar dimensions as in mentioned earlier in the case of the 2 bedroom conversions. These dimensions are based on average size of SSAs in Melbourne as required by the market. Some CSAs with similar dimensions of SSAs have been developed by the University of Melbourne and other private firms including UniLodge and demand has exceeded supply.

\section{Table 2 here}

In Table 2, it is proposed that both the retail and car park areas should be converted into coworking spaces which has gained popularity within the office market in Melbourne. It can be seen that the four retail spaces of size 220sq.m each has been combined into a single space of 880 sq.m. Furthermore, it is proposed the car park space be combined into a total space of 880sq.m for the coworking space. The bike space area was considered appropriate for the CSA and as a result, the switching did not affect that space.

\subsection{Justification for the Proposal}

The popularity of Australia as a destination for international students in higher education institutions has resulted in an increasing number of new international students leading to demand for student accommodation. For example, there was $9.7 \%$ growth in population of international students in higher education during the 2015/2016 academic year, and the State of Victoria had the highest proportion of international students coming into Australia during the year 2016 (JLL, 2016). Melbourne has also been adjudged as the most liveable city in the world for six consecutive times including 2016 (ABC, 2016) making it an attractive destination for international students. According to JLL, the student accommodation market has transitioned from a high level of strata title ownership into a full institutional asset class as part of portfolio of some institutional investors, and allocation to CSA may increase in portfolios (JLL, 2015). Moreover, in Melbourne, JLL estimates that total full time student population is 234,844 but, the number of student beds available is about 19,188 (JLL, 2016) indicating a significant shortfall. Discussion with industry players indicate that students have resorted to renting out rooms in shared houses, hostels and sharing rooms due to the shortage of accommodation.

The manner in which corporate offices are used is changing due to technological advancement, structural changes in population and the economy. For example, traditional offices such as the cellular and hive office models are being replaced by more agile, flexible workspaces that are interactive, technology enabled and encourage collaboration among the space users (Knight Frank, 2016). It is estimated that there are about 100 operators of coworking spaces as at Q2 of 2016 in Melbourne alone since the first flexible coworking space was opened in 2007, and the sector has recorded a 43\% growth between 2013-2015 (Knight Frank, 2016). There is positive outlook for coworking spaces because a key finding from a survey conducted by Knight Frank suggests that $61 \%$ of the operators plan to expand their operations in 2016. This is in anticipation of future growth of the sector and therefore, embedding a switching output strategy in the investment has the potential to benefit the investors and serve as a hedge against risk of potential disruptions in the property market.

\subsection{Methodology}


Firstly, the DCF model is used to determine the viability of the current proposed investment. DCF technique has two measures of profitability; net present value (NPV) and internal rate of return (IRR). The NPV is given by

$$
N P V=-I+\sum_{n=1}^{10} \frac{N O I_{1}}{(1+r)^{1}}+\frac{N O I_{2}}{(1+r)^{2}} \ldots+\frac{N O I_{t}}{(1+r)^{n}} \quad \text { Equation } 1
$$

Where:

$I=$ Initial investment of the development of the mixed use (purchase price)

$n=$ the investment horizon is 10 years based on standard practice and the real estate fund's life

$t=$ time a specific net operating income from rents is projected to be received by the investor

$r=$ the required discount rate expected by the investor

$N O I=$ the net operating income expected from the development at a specific time

Afterwards, the switching proposal is evaluated using both the DCF and ROA framework to determine the potential expected value of the investments and to justify spending the initial extra investment in flexibility or not. As the value of the switching option is tied to future uncertainties, it is evaluated using the real options framework. Specifically, the McDonald and Siegel (1986) model, which is based on similar assumptions as the Black and Scholes (1973).

However, the former model considered dividend payouts which represent the rental return in real estate applications. Because the switching output option is an infinite option exercisable at any time during the life of the option, the continuous time option pricing formula developed by SamuelsonMcKean and subsequently adapted by McDonald and Siegel (1986) is the most appropriate and given by;

$$
C=\left(V^{*}-I\right)\left(\frac{V}{V^{*}}\right)^{\beta}
$$

Equation 2

Where:

$C=$ The value of the switching output call option

$V=$ the current value of the investment determined using direct capitalisation

$I=$ the initial cost required for the investment in addition to the cost of switching from its current use to the proposed use

$\beta=$ the option elasticity

$V^{*}=$ the hurdle value of $\mathrm{V}$ and it is the optimal timing for the immediate exercise of the option to invest at that time and is given by

$$
V^{*}=I * \frac{\beta}{\beta-1}
$$

Equation 3

and the option elasticity $\beta$, is given by 


$$
\beta=\frac{1}{2}-\frac{r-y}{\sigma^{2}}+\sqrt{\left(\frac{r-y}{\sigma^{2}}-\frac{1}{2}\right)^{2}+\frac{2 r}{\sigma^{2}}} \quad \text { Equation } 4
$$

Where:

$r=$ the risk free interest rate

$y=$ annual net rental income cash yield for the switched mixed use building

$\sigma^{2}=$ expected annual volatility of underlying mixed-use property

The volatility of a specific use (space type) is given by

$$
\sigma_{1}=\sqrt{\frac{1}{N} \sum_{i=1}^{N}\left(x_{i}-\mu\right)^{2}} \quad \text { Equation } 5
$$

Where:

$\sigma_{1}=$ the standard deviation of the specific use or space

$\mathrm{N}=$ the number of observations in the data

$x_{i}=$ an observation in the data sample

$\mu=$ the mean for the sample data

\subsection{Data for DCF modelling (Original plan)}

The data for the project was provided by the investor including projected rents, occupancy levels, and potential costs of developing the project and operating it. According to Savills (2016) data from Core Logic RP Data, the median gross rents in North Melbourne for 1, 2, and 3 bedrooms were determined to be \$AUD360 per week (p/w), \$AUD480p/w and \$AUD670p/w respectively as shown in Table 1. Retail leases, which are normally on a net operating cost basis was determined to be \$AUD410/sq.m as shown in Table 1 (Savills, 2016).

\section{Table 3 here}

A CPI of $2.5 \%$ was adopted as the rental growth rate due to the long term target of inflation between $2 \%-3 \%$ (RBA, 2016). A weighted discount rate of $10.5 \%$ was derived from an average of 10 -year data on total return for property investments (units and retail) in the North Melbourne area where the property is located. The net operating income for year 1 for the financial feasibility analysis was determined at $\$ A \cup D 3,078,723$. The total initial investment required for the mixed use project was \$AUD46,047,500 as computed using the Rider Levett Bucknall (RLB) construction guide which is an accepted tool for determining construction costs in industry. A weighted average capitalisation rate of $5 \%$ was used to capitalise the net operating income (NOI) in year 11 to derive the resale value.

\subsection{Data for real option modelling}

On the real options modelling, weighted annual net rental yield $(y)$ for the switching option (CSA and coworking) was determined to be $7.3 \%$ based on data sourced from both Property Council of Australia (2016) and JLL (2016). Data for the commercial part (coworking) was from Property Council of Australia (2016), which included a 22-year average rental return for investments in offices. On the 
contrary, data for the CSA was from JLL (2016)and was a 4-year average rental return for investments in CSA in Australia. Even though the data is not a long time series, it is accepted as a limitation but serves as a starting point for modelling CSAs in practice because it is at the nascent stages of being considered an investment vehicle for large scale property investors in Australia. The extra amount (cost) needed to embedded in the switching output flexibility in the investment was calculated to be \$AUD7.6million (based on data from the investor) resulting in a total cost of $\$ A \cup D 53,654,547$. The current value of the mixed use development without flexibility (the switching output proposal) is estimated to be $\$ A U D 58,918,322$ using a direct capitalisation approach based on the market asset disclaimer (MAD) assumption. The weighted volatility of the proposed switching was calculated to be $6.6 \%$ and the risk free rate adopted was the average rate for a 10 -year Australian government bond, which was computed to be $2.45 \%$ (RBA, 2016). The total gross rent was indexed to CPI of $2.5 \%$ over the investment horizon which is an industry accepted practice. Vacancy rate for CSA and coworking of $15 \%$ and $10.4 \%$ respectively, maintenance and outgoings at a rate of \$AUD3,500 per student bed, sinking fund for capital expenditure of $4 \%$, and agent's fees of $4 \%$ were deducted from the gross rents to determine a NOI of $\$ A \cup D 3,990,564$ based on information received from JLL. A capitalization rate and selling costs of $5.6 \%$ and $5 \%$ respectively were used to arrive at the value of the inflexible switching output option.

\section{Table 4 here}

Other information used in modelling the switching output is displayed in Table 4, especially the output of the conversion of the building and resultant rental level for the investment. In Table 4, the switching output and the details of the resulting number of spaces after the switching and the rents are displayed. It can be seen that the number of SSA has increased from 164 to 414 due to the conversion and reduction in the per square metre foot print per SSA, hence increasing the number of SSAs. The retail space was converted into a coworking space that can be separately leased to tenants/occupiers. The potential gross rent from the SSAs and coworking is estimated to be $\$ A \cup D 6,673,680$ and $\$ A \cup D 415,360$ respectively. Therefore, the total potential gross rent estimated is $\$ A U D 7,089,040$ which is the sum of the potential gross rents from both studios and the commercial part of the apartment building. In Table 4, the rent levels achievable for the student shared accommodation is the same because they are all shared accommodation. This differs from the single student studios that requires a single person to occupy, as opposed to the SSAs which are shared by two or students, which have their separate rooms but shares facilities such as kitchen and living room. In essence, the single students studios have a greater degree of privacy as compared to the SSAs, hence, has a higher rent.

\subsection{Results and Discussion}

Results from the initial DCF analysis of the original inflexible design of the mixed use project indicated that the original plan was financially viable. The information on the profitability of the investment is shown in Table 5. NPV of the investment was estimated to be \$AUD1,189,411, an initial yield of $6.9 \%$ and an internal rate of return (IRR) of $11.5 \%$. Based on the results as shown in Table 5 and the DCF rules of decision making which stipulates that projects with NPV $>0$ should be accepted, the developer would have accepted and executed the project because of the potential profitability.

Table 5 here

Thus, all the measures of profitability suggested an immediate development of the project in its originally proposed design. The suggestion to proceed immediately with the project is in spite of the 
numerous uncertainties that have the potential to render the project financially unviable midway through the development or during the investment horizon. As a result, even though the financial viability was positive, the investor did not consider the impact of future changes in the market (either upside or downside) in the financial viability analysis, which can have serious financial implications on the viability of the investment during the investment life time. Due to uncertainties surrounding inputs into the DCF modelling, it is important to examine the impact of changes in these inputs on the financial success of the mixed-use development project and to demonstrate the potential risks associated with the project warranting the embedding of flexibility to switch. Through sensitivity analysis of the uncertain inputs using @Risk software, it was determined that the occupancy rates had the greatest impact, followed by rents, initial investment, discount rate and capitalisation rate respectively. In the sensitivity analysis output diagram in Figure 3, a $10 \%$ downward change in occupancy rate from $94.7 \%$ to $85.2 \%$ has the potential impact of resulting in a negative NPV of $\$-4,651,302$ rendering the investment financially unviable. This is similar to all the other variables because a $10 \%$ downward change in rent, initial investment, discount rate and capitalisation rate has a potential impact of resulting in negative NPVs of $\$-3,534,253, \$-3,415,309$, $\$-2,157,401$ and $\$-107,425$ respectively. Therefore, the investors should be cautious in their extreme optimism regarding the potential profitability of the investment. This also demonstrates the risks bedevilling the intended project and the need for the switching output option as a hedge against potential downturn in the market.

\section{Figure 3 Sensitivity analysis}

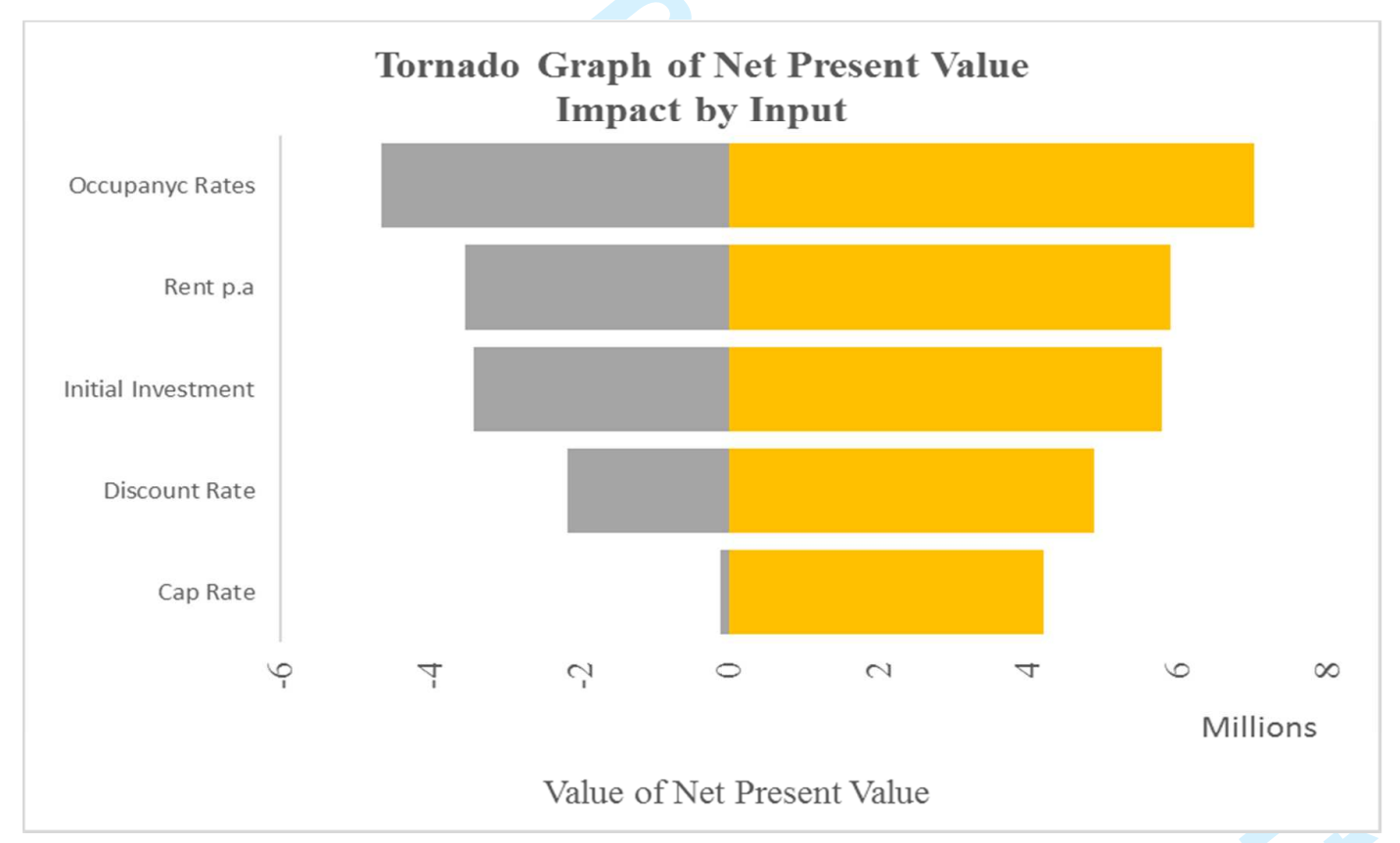

Source: Author, 2017

The proposed switching output was also evaluated using the DCF technique without accounting for flexibility. The NPV for the inflexible switching output is $\$ A \cup D 2,468,479$, which is about a double of the NPV for the original plan. This result was achieved, despite the higher discount rate used for the evaluation of the switching output proposal as compared to the original inflexible proposal. Secondly, the IRR for the inflexible switching proposal is higher $(12.95 \%)$ than the original inflexible design (11.5\%). Therefore, the investors may decide to choose the inflexible switching proposal instead of the original inflexible idea subject to planning permission. Similarly, the initial yield that is 
used by investors and practitioners to determine initial profit levels was higher in the case of the inflexible switching proposal at $7.4 \%$ as compared to the original inflexible design of $6.9 \%$. Using the DCF analogy and decision making rules in both cases, the inflexible original and switching proposals are both financially viable albeit the inflexible switching proposal produces higher returns for the investor. If the main objective of the investor is for profit maximization, the obvious choice is the strategy that delivers the best returns and in this case it is the inflexible switching proposal that must be executed. However, it is also possible that the investor may be developing to diversify the portfolio and may have other reasons of instigating the development. In such a case, the investor may choose to develop the inflexible original design of an apartment with retail but still keep the inflexible switching output option as a strategy to be pursued in future as a buffer against possible downturn in demand for residential apartments. Obviously this is a decision to be made by the investor depending on the risk-return profile and strategic objectives.

Since the flexible switching proposal was a hedge against uncertainties and risks, it is important to examine it in the context of immediate exercise of the flexible switching output option and future potential to act as a buffer against potential losses. The hurdle rate/value $\left(\mathrm{V}^{*}\right)$ which triggers immediate exercise of the decision to switch the output was determined to be \$AUD84,479,938. This implies that, until the total value of the proposed switching output is equal to this amount, the conversion should not be executed by the investor. Thus, during the holding period of the investment, should the hurdle value/rate of the switching proposal be achieved, there is an immediate trigger to exercise the option of converting the units into CSA and coworking space. However, due to the fact that the total value of the switching proposal at present is lower than the hurdle value, the switching proposal becomes an embedded flexible strategy of waiting to invest when the timing is right.

The real option value associated with the flexible switching output option was determined to be \$AUD11,481,445 which is the payoff from investing in the flexible switching output option and exercising it at the right time in future. This value is compared to the extra cost of embedding the flexibility to determine the payoff associated with the extra investment. A positive payoff is an indication of future profitability and a negative payoff is an indication of losses. Since the extra investment was $\$ A \cup D 7,600,000$, the payoff is $\$ A \cup D 3,881,445$ representing the potential profit from the flexible investment. Thus, an upfront investment to retain the flexibility to switch output to the newly proposed design in future is acceptable and justifiable through the ROA framework because the payoff from the investment is positive and higher than the extra initial investment.

It is plausible to argue that if students are "forced" to live in apartments due to shortage of student accommodation, weekly rent levels for apartments will increase leading to the development of more apartment buildings by developers to capitalise on the profits thereof. Besides, student accommodation is less expensive. However, the switching option is beneficial because it increases the rent per square metre of space for the student accommodation and hence, the total profitability. For example, in the case study under consideration a 1 bedroom apartment of $25 \mathrm{sqm}$ has a net rent/sqm of \$AUD14.4 whereas the same size of space when switched can have 2SSA's with a combined net rent/sqm of \$AUD17.4. This is similar for all the other rental spaces ( 2 and 3 bedrooms units when switched into 3 SSA's and 5 SSA's respectively). As a result, the switching is likely to deliver better profitability/return than the apartment. Moreover, the switching can also serve as a way to diversify the portfolio of the investors as they have a long term horizon for this investment. Thus, a downturn in the apartment market would be offset by switching to student accommodation in future with ease due to the embedded option, thereby mitigating the overall risk associated with the investment. 
The switching option has the potential to offer affordability which is an important consideration in student rentals. In student accommodations, the rent paid includes other bills such as electricity, water and gas, whereas these bills are paid by occupiers in apartment buildings. As a result, students find it cheaper as compared to renting from the private market. Living in students apartments offer the necessary privacy as adults which is lost when students share accommodation in an apartment building. This feature of student accommodations make it a sought after option by students. The switching option therefore is mutually beneficial to both the developers and students, hence the developer embedding it in the design phase of the investment and capitalising on it in future as a risk mitigation strategy is reasonable.

The application of the switching output option to a real life case study suggests that investors and other practitioners can adopt the strategy and use it in their investment analysis when facing uncertainty regarding future demand, vacancy, rents and property values in decision making. The nature of property investments particularly the difficulty of prognosis and illiquidity of the market requires the use of strategic initiatives to deal with unforeseen impacts of uncertainties arising from imperfect information about property investments. Due to the durability of property as an asset class with long term horizon, it is important that strategies such as switching output are embedded in the investment analysis from the inception. This ensures that investors are able to capitalise on the upside opportunities in the market while at the same time limiting downside losses. The switching output strategy proposed and evaluated can serve as a hedge against potential loss should demand for units in apartment buildings and retail decrease as a result of changes in the economic environment necessitated by exogenous factors beyond the control of the investor.

The switching option serves as a potential upside opportunity for the ID involved in this project to the extent that a downturn in the apartment market triggers an immediate switch to safeguard against high vacancy. Besides there is an increased net rent/square metre when the switching option is exercised. As the market for student apartments is in its early stages of development, the switch may also serve as an entry strategy for the ID in case it becomes necessary to venture into the development of students apartments in future. The students on the other hand will benefit from having privacy and decreased rents as compared to renting apartments and living with strangers in some cases.

In the development of student housing, universities are mostly involved either as owners (manages the property in their student housing system) or advertises these student apartments on behalf of developers. This is a means of attracting local and international students who may be required to travel to a different city to study. For example, RMIT University advertises/promotes private student apartments such as Urbanest, UniLodge and Student Housing Australia on their website. Since the development is closer to University of Melbourne ( 5 minutes by walk) and RMIT University students village ( 3 minutes by walk), the ID can seek the future involvement of these two universities in terms of disposing of the building to the university at the end of the investment horizon. This is plausible due to the continuous expansion and attraction of international students to Australia every year. By doing so, the developer basically creates an option to sell (to a capable potential client-the university) when the need arises. Thus, an exit strategy is created by the ID awaiting the right time to exercise the option. However, if in the future universities involved are unwilling to acquire the development due to downsizing or dwindling student numbers, the ID has the opportunity to sell the units individually to private property investors or to a strategic investor. This is prevalent in the student housing market in Australia because currently, most of the units in student apartments are owned by individual investors on strata title. 
The use of volatility as measure of risk and uncertainty associated with the investment offers a direct approach to dealing with risks rather than the use of discount rates to indirectly represent risks as pertains in the DCF framework. Besides, the use of discount rates as a measure of risk does not capture the magnitude of all risks that investors have to grapple with in property investments. In view of this, the real options framework that directly treats the uncertain variables and develops a strategy to deal with uncertainty is plausible. This improves the financial evaluation decision making of investors and other stakeholders in the property industry.

Option pricing techniques have been used in real estate and construction sector to evaluate case studies from different real estate markets under different contexts. Obviously, what works in one geographical market may not work in another geographical market. In view of this, the case study under consideration has delivered initial results of the switching output application from the Australian real estate market and demonstrated the applicability of options valuation techniques to a real case study. Especially, the conversion of the residential units in the apartment building to CSA and retail to a coworking space is new in the literature and will add to the existing body of knowledge on switching output application. Findings from a single switching output application found in the literature was also positive albeit timing was not optimal for the exercise of the option (Throupe et al., 2012). The current study differs from this earlier study in terms of the proposed switching application and the geographical context of the case study.

In practice, it is possible that developers, valuers, investors and other property stakeholders may be implementing or have implemented this in the past. For example discussions with practitioners revealed that some conversions of hotels to apartments have taken place in Australia in the past. Some practitioners may be contemplating on implementing some of these strategies in their investments in one way or another. It is possible practitioners may be doing so without using the right technique, considering that DCF is the most widely used technique and real options valuation techniques is relatively new and yet to be accepted as a decision making tool. This application therefore comes as an important demonstration of the use of options pricing techniques in the real estate and construction sector in the Australian property market and delivers further evidence needed to support the adoption of the option pricing techniques in practice.

\subsection{Conclusion}

The study used an option pricing technique to evaluate and justify investments in flexibility of embedding an output switching option in an actual investment project, which can serve as a hedge against potential future risks of vacancy and decreased demand for a mixed use project. The originally proposed investment was a residential apartment building with ground floor retail and a car park. It was argued that the proliferation of similar developments has the potential impact of negatively affecting demand, hence the investors needed to have a flexible strategy to deal with future uncertainties that could render the project financially unviable at some point in time in future.

The switching output option was proposed as a possible flexible strategy to embed in the investment from the inception of the project to serve as a risk management tool during the life of the investment. In view of this, the investors had to spend an extra amount to embed the flexibility of being able to convert the units and retail into CSA and co-working space in the future. As such decisions can only be justified contingent upon a specific situation occurring during the investment period, the DCF framework could not be used to evaluate contingent decisions. As a result, the real options valuation technique developed by (McDonald and Siegel, 1986) was used to evaluate the switching output option. 
Results and findings indicated that the switching output option is capable of serving as a risk management strategy which can aid an investor to alter course mid-way through an investment horizon when market dynamics impact negatively on a specific investment asset class. The comparative analysis between results from DCF and option pricing techniques resulted in objective analysis of the financial feasibility evaluation of the present case study and enhanced the profitability and risk analysis of the investment project. In this case study, results show that the flexible switching output option is capable of doubling the profitability of the investment at the optimal timing of exercising the option to execute the switch. Moreover, extra expense in executing the switching output was deemed necessary because the expected value exceeded the cost of exercising the option at the optimal time. However, because the timing is not right, the investor has to wait until the value of the proposed switching far exceeds the cost to justify exercising the option.

The switching option serves as a potential upside opportunity for the ID involved in this project to the extent that a downturn in the apartment market triggers an immediate switch to safeguard against high vacancy. Besides there is an increased net rent/square metre when the switching option is exercised. As the market for student apartments is in its early stages of development, the switching option may also serve as an entry strategy for the ID in case it becomes necessary to venture into the development of student apartments in future. The students on the other hand will benefit from having privacy and decreased rents as compared to renting apartments and living with strangers in some cases.

The reality is that most practitioners do not recognise the value of these embedded options in real estate investment and development projects, primarily due to the conservative nature of property practitioners and the relative paucity of evidence to support the adoption of the ROA method in practice. The ability of practitioners to identify and evaluate all possible real options in a development or an investment project is important and can enhance investment decision making of practitioners. This is especially true, during the designing phase of a project, investors can embed such flexibility with the intention to capitalise on emerging opportunities in the economic environment to maximise profits due to changes in the future while at the same time limiting downside losses.

\section{REFERENCES}

ABC. (2016), Melbourne ranked world's most liveable city for sixth consecutive year by eiu [Datafile]. Available: $\quad$ http://www.abc.net.au/news/2016-08-18/melbourne-ranked-worlds-mostliveable-city-for-sixth-year/7761642 [Accessed 28/11/ 2016].

Black, F. and Scholes, M. (1973), 'The pricing of options and corporate liabilities', The Journal of Political Economy, Vol. 81, No. 3, pp. 637-654.

Cardin, M.-A., de Neufville, R., Geltner, D. and Deng, Y. (2013), 'Design catalogs: A practical real options valuation tool for real estate design and development planning', paper presented to IRES2013-007, Institute of Real Estate Studies, National University of Singapore, Singapore, February 2013.

Cheah, C.Y. and Liu, J. (2005), 'Real option evaluation of complex infrastructure projects: The case of dabhol power', Journal of Financial Management of Property and Construction, Vol. 10, No. 1 , pp. 55-68.

Cocco, J.F. (2004), 'Portfolio choice in the presence of housing', The Review of Financial Studies, Vol. 18, No. 2, pp. 535-565. 
Damodaran, A. (2012), Investment valuation tools and techniques for determining the value of any asset,John Wiley \& Sons Inc, Hoboken, New Jersey.

de Neufville, R. (2003), 'Real options: Dealing with uncertainty in systems planning and design', Integrated Assessment Vol. 4 No. 1, pp. 26-34

de Neufville, R., Scholtes, S. and Wang, T. (2006), 'Real options by spreadsheet: Parking garage case example', Journal of Infrastructural System, Vol. 12, No. 2, pp. 107-111.

DELWP (2011), Melburne planning scheme: Amendment c163 student housing policy, Department of Environment, L., Water and Planning, City of Melbourne.

DELWP (2016), Better apartment design standards: New apartment design standards for victoria, Department of Environment, L., Water and Planning, City of Melbourne.

Dixit, A.K. and Pindyck, R.S. (1994), Investment under uncertainty, Princeton University Press, Princeton, New Jersey.

Dixit, A.K. and Pindyck, R.S. (1995), 'The options approach to capital investment', Harvard Business Review, Vol. 73, No. 3, pp. 105-115.

Dortland, M.V., Voordijk, H. and Dewulf, G. (2012), 'Towards a decision support tool for real estate management in the health sector using real options and scenario planning', Journal of Corporate Real Estate, Vol. 14, No. 3, pp. 140-156.

French, N. and Gabrielli, L. (2005), 'Discounted cash flow: Accounting for uncertainty', Journal of Property Investment \& Finance, Vol. 23, No. 1, pp. 75-89.

Geltner, D. and de Neufville, R. (2012), 'Uncertainty, flexibility, valuation and design: How 21st century information and knowledge can improve 21st century urban development-part ii of ii', Pacific Rim Property Research Journal, Vol. 18, No. 3, pp. 251-276.

Gibson, V. (2001), 'In search of flexibility in corporate real estate portfolios', Journal of Corporate Real Estate, Vol. 3, No. 1, pp. 38-45.

Goetzmann, W.N. (1993), 'The single family home in the investment portfolio', Journal of Real Estate Finance and Economics, Vol. 6, No. 3, pp. 201-222.

Goodman, J. (2003), 'Homeownership and investment in real estate stocks', Journal of Real Estate Portfolio Management, Vol. 9, No. 2, pp. 93-105.

Greden, L., de Neufville, R. and Glicksman, L. (2005), 'Management of technology investment risk with real options-based design: A case study of an innovative building technology', paper presented to 9th Annual Real Options Conference, Paris, France, February 21,.

Greden, L. and Glicksman, L. (2005), 'A real options model for valuing flexible space', Journal of Corporate Real Estate, Vol. 7, No. 1, pp. 34 - 48.

JLL (2015), Australian student accommodation market update 2015, JLL, Sydney.

JLL (2016), Australian student accommodation market review, JLL, Sydney.

JLL (2016), Residential commentary-melbourne apartment market, JLL, Sydney.

Knight Frank (2016), Melbourne's coworking culture: Reserach insight, Knight Frank, Melbourne.

Kogut, B. and Kulatilaka, N. (2001), 'Capabilities as real options', Organization Science, Vol. 12, No. 6, pp. 744-758.

Lander, D.M. and Pinches, G.E. (1998), 'Challenges to the practical implementation of modeling and valuing real options', The Quarterly Review of Economics and Finance, Vol. 38, No. 3, pp. 537-567.

Leung, B.Y. and Hui, E.C. (2002), 'Option pricing for real estate development: Hong kong disneyland', Journal of Property Investment \& Finance, Vol. 20, No. 6, pp. 473-495.

Lin Lee, C. (2008), 'Housing in australia as a portfolio investment', International Journal of Housing Markets and Analysis, Vol. 1, No. 4, pp. 352-361.

Loizou, P. and French, N. (2012), 'Risk and uncertainty in development', Journal of Property Investment \& Finance, Vol. 30 No. 2, pp. 198 - 210.

Lucius, D.I. (2001), 'Real options in real estate development', Journal of Property Investment \& Finance, Vol. 19, No. 1, pp. 73-78. 
McDonald, R.L. and Siegel, D. (1986), 'The value of waiting to invest', Quarterly Journal of Economics Vol. 101, No. 4, pp. 707-727.

Oppenheimer, P.H. (2002), 'A critique of using real options pricing models in valuing real estate projects and contracts', Real Estate Finance, Vol. 2, No. 3, pp. 221-233.

Patel, K. and Paxson, D. (1998), 'Real options based approach to valuation of property development and investment', Property Research Digest, pp. 1-11.

Paxson, D. (2005), 'Multiple state property options. ', The Journal of Real Estate Finance and Economics, , Vol. 30, No. 4, pp. 341-368.

Paxson, D.A. (2005), 'Multiple state property options', The Journal of Real Estate Finance and Economics, Vol. 30, No. 4, pp. 341-368.

Property Council of Australia (2016), The property council/ipd australia all property iindex, Property Council of Australia/IPD, Sydney.

Quigg, L. (1993), 'Empirical testing of real option-pricing models', The Journal of Finance, Vol. 48, No. 2, pp. 621-640.

Investigator. (2016), Cash rate: Monetary policy changes, july, 2016 (data file) [Online]. Sydney. Available: http://www.rba.gov.au/statistics/cash-rate/.

RBA. (2016), Inflation target [Datafile]. Sydney: Reserve Bank of Australia. Available: http://www.rba.gov.au/monetary-policy/inflation-target.html [Accessed 25/10/2016].

Savills (2016), Quarter times: Melbourne retail q2/2016, Savills, Melbourne.

Shapiro, E., Mackmin, D. and Sams, G. (2013), Modern methods of valuation,Taylor \& Francis, New York, NY.

Sirmans, C.F. (1997), 'Research on discounted cash flow models', Real Estate Finance, Vol. 13, No. 4, pp. 93-95.

Slaughter, E.S. (2001), 'Design strategies to increase building flexibility', Building Research \& Information, Vol. 29, No. 3, pp. 208-217.

Throupe, R., Stephen, S., Zhong, J. and Chen, H. (2012), 'Real option analysis: A switching application for mixed-use real estate development', Pacific Rim Property Research Journal, Vol. 18, No. 3, pp. 277-291.

Titman, S. (1985), 'Urban land prices under uncertainty', The American Economic Review, Vol. 75, No. 3, pp. 505-514.

Trigeorgis, L. (1993b), 'Real options and interactions with financial flexibility', Financial Management, Vol. 22, No. 3, pp. 202-224.

Trigeorgis, L. (1996), Real options: Managerial flexibility and strategy in resource allocation, MIT press, Cambridge, MA.

Trigeorgis, L. and Mason, S.P. (1987), 'Valuing managerial flexibility', Midland Corporate Finance Journal, Vol. 5, No. 1, pp. 14-21.

Urban Melbourne. (2015), The principal: Flemington road's latest addition [Datafile]. Urban Melbourne. Available: https://urban.melbourne/development/2015/09/30/principalflemington-roads-latest-addition [Accessed 4/11/2016].

Vimpari, J. (2014). Is there hidden value in real estate investments?-real options analysis provides rationale to contingent investment decisions. $\mathrm{PhD}$, Aalto University.

Vimpari, J., Kajander, J.-K. and Junnila, S. (2014), 'Valuing flexibility in a retrofit investment', Journal of Corporate Real Estate, Vol. 16, No. 1, pp. 3-21.

Williams, J.T. (1991), 'Real estate development as an option', Journal of Real Estate Finance and Economics, , Vol. 4, No. 2, pp. 191-208 